Dialectologia 18 (2017), 107-127.

ISSN: 2013-2247

Received 1 January 2015.

Accepted 16 March 2015.

\title{
A SOCIOLINGUISTIC ANALYSIS OF TABOOS AND EUPHEMISMS IN AN ARAB COMMUNITY IN IRAN
}

\author{
Seyyed Hatam TAMIMI SA'D \\ Urmia University \& Iran Language Institute (ILI), Iran* \\ Shtamimi90@gmail.com
}

\begin{abstract}
The current ethnographic study sought to investigate the discourse strategies that Arab interlocutors employ to euphemize tabooed subjects raised in interaction. The objective was threefold: a) to identify topics deemed as tabooed by Arabs, b) to find out the strategies used to euphemize tabooed topics and c) to account for the reasons behind the strategies employed. The data were gathered using ethnography and observations done on a period of two years by the researcher himself in the Arab community in Khuzestan, Iran. The observations demonstrated that such issues as sex, death, health and diseases, politics, religion, possessions, talents, abilities and family relations are construed as tabooed by Arab interlocutors. The findings also indicated that interlocutors sought recourse in such strategies as: a) use of euphemistic terms and expressions, b) silence c) change of tone, prosody and eye contact, d) criticism of the interlocutor to deal with taboo. Furthermore, taboo topics were mostly raised by male interlocutors and only occasionally by female interlocutors and while males hardly ignored or euphemized such topics, females did so very frequently. It is concluded that taboo, euphemism and (im)politeness are highly intertwined and considerably influenced by such factors as age, gender, social distance and so on.
\end{abstract}

\section{Keywords}

Arabic, discourse strategies, euphemism, politeness, taboo

* No. 1, Iran Language Institute (ILI), $3^{\text {rd }}$ Eastern Street, Kianpars, Ahvaz, Khuzestan, Iran. Zip code: 61559 16343. 


\section{UN ANÁLISIS SOCIOLINGÜÍSTICO DE TABÚES Y EUFEMISMOS EN UNA COMUNIDAD ÁRABE EN IRÁN}

\section{Resumen}

Este estudio etnográfico se propone investigar las estrategias de discurso que los interlocutores árabes usan para tratar eufemísticamente temas tabú surgidos en interacción. El objetivo es triple: a) identificar temas considerados como tabú por los árabes, b) conocer las estrategias utilizadas para tratar eufemísticamente temas tabú y c) explicar las razones que motivan las estrategias empleadas. Los datos fueron recopilados por el propio investigador usando la etnografía y las observaciones realizadas en un período de dos años en la comunidad árabe en Khuzestan, Irán. Las observaciones demuestran que cuestiones como el sexo, la muerte, la salud y las enfermedades, la política, la religión, las posesiones, los talentos, las capacidades y las relaciones familiares son interpretadas como tabúes por interlocutores árabes. El estudio también indicaba que los interlocutores usaban como recurso estrategias tales como: a) el uso de términos y expresiones eufemísticas, b) el silencio c) el cambio de tono, la prosodia y el contacto visual, d) la crítica al interlocutor para tratar el tabú. Además, los temas tabú fueron en su mayoría planteados por los interlocutores masculinos y sólo ocasionalmente por las mujeres interlocutoras y mientras que los hombres apenas ignoraban o trataban eufemísticamente tales temas, las mujeres lo hacían con mucha más frecuencia. La conclusión es que el tabú, el eufemismo y la (des)cortesía están altamente entrelazados e influenciados considerablemente por factores como la edad, el género, la distancia social, etc.

\section{Palabras clave}

Árabe, estrategias del discurso, eufemismo, cortesía, tabú

\section{Introduction}

Language use is a highly complex phenomenon which is under the influence of a variety of factors, social, linguistic, personal and cultural. In interacting with each other, interlocutors most often do not express what they intend to voice as explicitly as they wish. Instead, they often have recourse to what has been called 'conversational implicature' to express what they have in mind in an indirect and therefore implicit way (Papi 2009). One of the sociological aspects of language is the presence of what has been called 'taboo' and 'taboo words'. These are said to be part of every culture (Qanbar 2011) and are believed to be rooted in social constraints (Allan \& Burridge 2006). According to Freud (1913 [2001], 21), the word 'taboo' is Polynesian in origin and 
using taboo language is a double-edged sword as what is taboo can be deemed as both 'sacred', 'consecrated' and 'forbidden' and 'unclean'.

Taboo language is as old as the human being himself (Keturi \& Lehmonen 2012). Taboos have been defined in similar ways. Steiner (1967, as cited in Qanbar 2011: 87) proposed the following definition of taboos: "any prohibitions which carry no penalties beyond the anxiety and embarrassment arising from a breach of strongly entrenched custom". Bussmann's (2006: 1173) definition includes the reasons behind considering an issue a taboo and defines a taboo as "a term that is avoided for religious, political, or sexual reasons and is usually replaced by a euphemism" and offers the example of rest room or bathroom as euphemistic terms for toilet. Taboos are one of the social phenomena through which language change comes about and seem to be characteristic of languages (Malmkjær 2002). To avoid taboo words, interlocutors employ what is called euphemism defined as "a pleasant replacement for an objectionable word that has pejorative connotations" such as to pass on for 'to die' (Bussmann 2006: 388). Similarly, Cruse (2006: 57) defined a euphemism as follows: "An expression that refers to something that people hesitate to mention lest it cause offence, but which lessens the offensiveness by referring indirectly in some way". The process through which certain words are avoided is called tabooization (Bussmann 2006).

The constraints of the social context are believed to be the origin of taboo language. According to Allan \& Burridge (2006: 1), "Taboos arise out of social constraints on the individual's behaviour where it can cause discomfort, harm or injury". This position has been adopted by many other researchers as well (e.g., Isbuga-Erel 2008).

\section{Iran and Khuzestan's Arab Community}

Located in southwestern Asia, Iran, officially the Islamic Republic of Iran, is composed of 31 provinces and is bounded to the north by Azerbaijan, Armenia, Turkmenistan, and the Caspian Sea, to the east by Pakistan and Afghanistan, to the south by the Persian Gulf and the Gulf of Oman, and to the west by Turkey and Iraq (Encyclopaedia Britannica 2014). The official language of Iran is Farsi or Persian. Arabs 
constitute a community of 1.5 million people ( $2 \%$ of the whole population of Iran). Iranian Arabs live in the provinces of Khorasan, Fars and Khuzestan, with Khuzestan hosting the vast majority of Arabs in Iran (Wikipedia 2014). The map of the province of Khuzestan is provided in Figure 1.

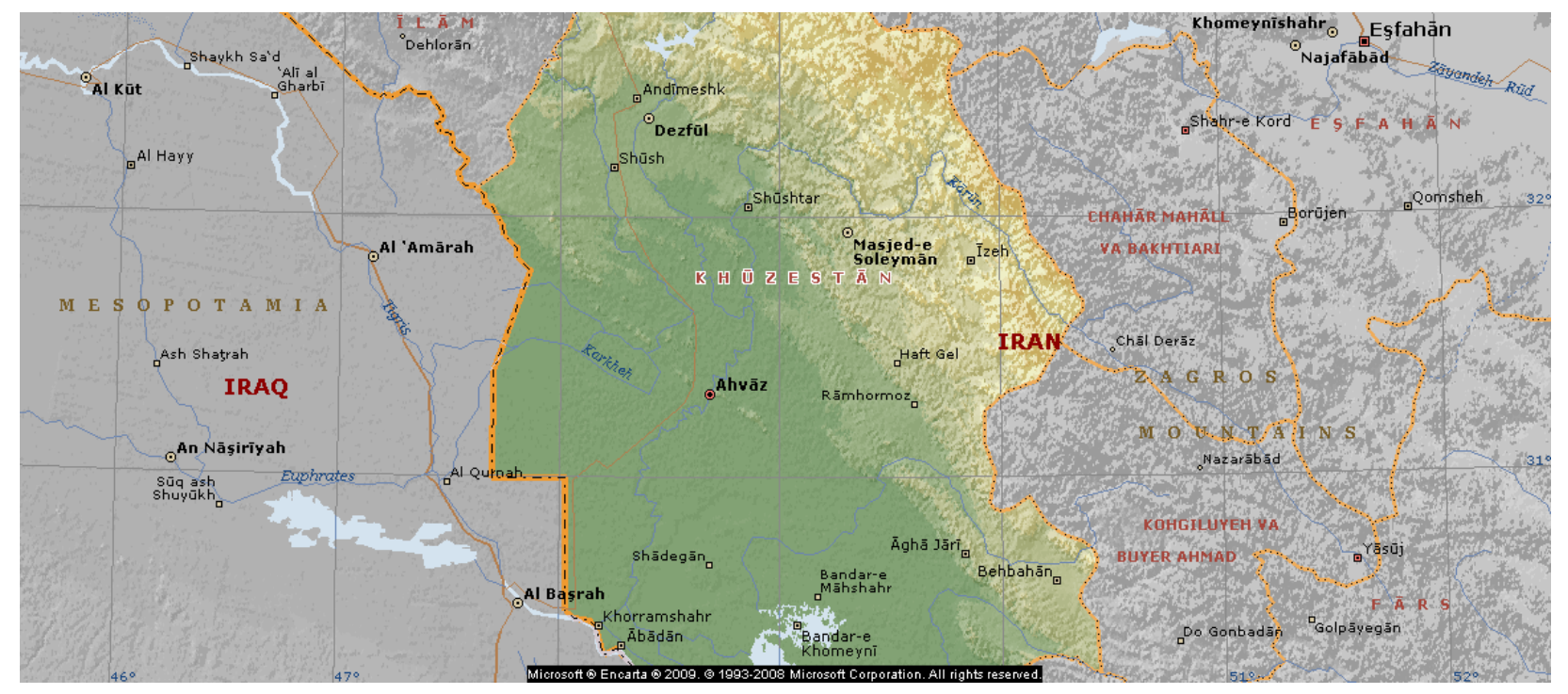

Figure 1. The map of the Province of Khuzestan (source: Microsoft ${ }^{\circledR}$ Encarta ${ }^{\circledR}$ 2009. (C) 1993-2008 Microsoft Corporation. All rights reserved).

\subsection{Objectives}

The objective of the present study is threefold. First, the study sets out to investigate the issue of taboo among the Arab community of Iran to see what categories of social interactions and what topics and subjects fall under the rubric of this concept. Second, it is attempted that the discourse strategies utilized to avoid the use of taboos be identified. Finally, the study attempts to shed light on the reasons for the use of certain strategies with certain types and categories of taboos. Based on the stated objectives, the study, therefore, addresses the following three research questions with regard to the Arab community of Khuzestan, Iran:

1. What categories and topics fall under the rubric of taboos in Arabic?

2. What discourse strategies are utilized to replace or avoid the use of taboos in Arabic? 
3. What is the use of different discourse strategies with different topics of taboos based upon in Arabic?

\section{Review of literature}

In recent years, the line of research on the socio-pragmatic aspects of language and language use has been increasing very rigorously. In this regard, due to their significant role in impacting on the interactions among interlocutors, taboos as well euphemisms have been the subject of research in various societies and cultures from a vast variety of aspects (e.g., Ahmad, Ghani, Alam \& Gul 2013; Allan \& Burridge 2006; Chinyanganya 2013; Epoge 2013; Fernández 2008; Isbuga-Erel 2008; Lie 2013; LinfootHam 2005; Mbaya 2002; Mirza Suzani \& Yarmohammadi 2013; Mwanambuyu 2011; Qanbar 2011; Radulović 2012; Talley \& Hui-ling 2012; Vernerová 2013, to name but a few). Epoge (2013) undertook a study of taboos in Cameron English and Qanbar (2011) investigated them in the Arab society of Yemen. Similarly, Ahmad et al. (2013) focused on the linguistic taboos in Pashtoon society in Pakistan, taking into consideration the religious, cultural and social factors that prompted the use of taboos. They found that while certain taboos are shared by most societies, certain others are unique to the Pashtoon society. Another recent study on taboo language analyzed the differences between males and females in using taboo/proscribed language in Taiwan (Talley \& Huiling 2012). The results supported the long-held belief according to which gender is an influential factor in language use with females' language being more 'decent'. Euphemisms have been examined in different contexts. The African context is one flourishing example. Mbaya (2002) investigated the nature of euphemisms in relation to the pursuant custom of avoiding the naming of those people who are connected by marriage called laguu or lagacha. Considering such factors as the interlocutors' age, sex, relative power and so on and basing her analysis on such theories as politeness, speech act and conversation analysis, Mwanambuyu (2011) examined them in the African context of Zambia. 
Literary texts have also been examined in light of research on taboo and euphemism. For instance, Linfoot-Ham (2005) based his diachronic analysis on novels such as Jane Austen's Emma and D. H. Lawrence's Lady Chatterly's Lover and Fiona Walker's Well Groomed which span 180 years. Linfoot-Ham analyzed these novels because of the common sexual themes recurrent in them and intended to investigate how word choice had shifted over time. The results demonstrated that word choice has changed so much that even a comprehensive framework such as that proposed by Warren (1992) cannot account for the examples of euphemisms found in the novels mentioned above. In the Turkish context, Isbuga-Erel (2008) analyzed, based on some frameworks within Critical Discourse Analysis (CDA), those literary texts related to 'incest', a taboo topic, that have been translated. Isbuga-Erel posited that such translation is mainly governed by social constraints and confines. In a similar vein, Fernández (2008) focused on the euphemism-dysphemism distinction to analyze sexrelated taboos in light of Conceptual Metaphor Theory as proposed by Lakoff \& Johnson (1980). The study concludes that metaphors can substantially contribute to the realization of taboos through euphemisms. This study confirmed the hypothesis that the use of euphemisms is under the influence of a host of factors.

The classification of euphemisms has also been the subject of some attention. For instance, in Radulović's (2012) study, the analysis of euphemisms was based upon their division into positive and negative. The outcomes demonstrated that while positive euphemisms are easy to distinguish and their use is favorable, this is not the case with negative euphemisms. As mentioned earlier on, the research line on taboo has been extensively rigorous. Vernerová (2013) stepped into the world of advertising, analyzing how the elements which caused an advertisement to sound profane, inappropriate and insulting. Vernerová argued that a variety of factors, religious, sexual and nakedness, both verbal and non-verbal, are at work which make an advertisement sound inappropriate in public. Translation of taboo words from English into Norwegian in movie subtitles was the theme of another study which found out that linguistic sanitation was at work to moderate the highly tabooed language used by the characters of the movies (Lie 2013). Chinyanganya's (2013) survey, done at Bindura Hospital, focused on taboos in the discourse of HIV/AIDS in Shona, an African language, in which 
sex is regarded as a taboo subject. This study revealed that the hospital personnel develop their own linguistic strategies to deal with this topic and to communicate their message which included references to HIV/AIDS.

In the Iranian context, Mirza Suzani \& Yarmohammadi (2013) examined the relationship between the Cooperative Principle (CP), its maxims, Politeness Principle (PP) and the use of euphemisms. Their study showed that utilizing euphemistic expressions results mainly and mostly in the flouting of the manner maxim of the CP and least frequently in the flouting of the quantity maxim.

Arabs in Iran constitute of a population of 1.5 million with unique religious, social, marriage and hospitality, among others, customs sometimes converging with those Arabs living beyond the borders of the Persian Gulf and at times diverging from them and blending into the Iranian side. This community and their ethnolinguistic traditions and customs deserve much attention on the part of researchers as very few, if any, research studies have examined this issue thus far. The current research study was motivated mainly by the dearth of research studies in this regard. As the objective of the current study, examining taboos, and subsequently the euphemistic language that is utilized to mitigate them, can yield startling insights into the nature of this remarkable sociolinguistic phenomenon.

\section{Method}

\subsection{Instrument}

Since the current study is ethnographic the data were collected using persistent observations which are the primary data collection tool and which yield naturally occurring data (Ary, Jacobs \& Sorensen 2010). This type of data requires that the contextual factors such as the interlocutors' gender, their role relationships, and so on be taken into account when the data are gathered. 


\subsection{The corpus}

The present study is an ethnography which is defined as "the in-depth study of naturally occurring behavior within a culture or entire social group" (Ary, Jacobs \& Sorensen 2010: 459). According to Ary, Jacobs \& Sorensen (2010), cultural patterns, the relationship between culture and societal behavior are among the most significant aspects that an ethnographic study should investigate. The data of the present study are based on the corpus of examples of taboos collected over a period of two year (2013 and 2014) by the researcher. These instances were analyzed contextually as is done in qualitative data analysis.

\subsection{Procedure and data analysis}

The current study benefited from rich and detailed description as its most pervasive feature of data analysis since a qualitative study deals mostly with phenomena at the discoursal level with the contextual cues and factors, relationships in mind. Put differently, it was attempted that the analysis of the data be done with an eye on the sociopragmatic factors. More precisely, the data analysis was based on the application of and taking advantage from politeness and face theory, conversation analysis as well as speech act theory wherever appropriate.

\section{Findings and Discussion}

\subsection{Tabooed Interactional Areas}

Studying taboo subjects entails, first, an understanding of the areas that fall under this 'forbidden' rubric. This issue was the subject of the first research question put forward earlier in this study. Roughly speaking, the findings revealed that the following include elements of taboo and thus should be dealt with cautiously by interlocutors: 


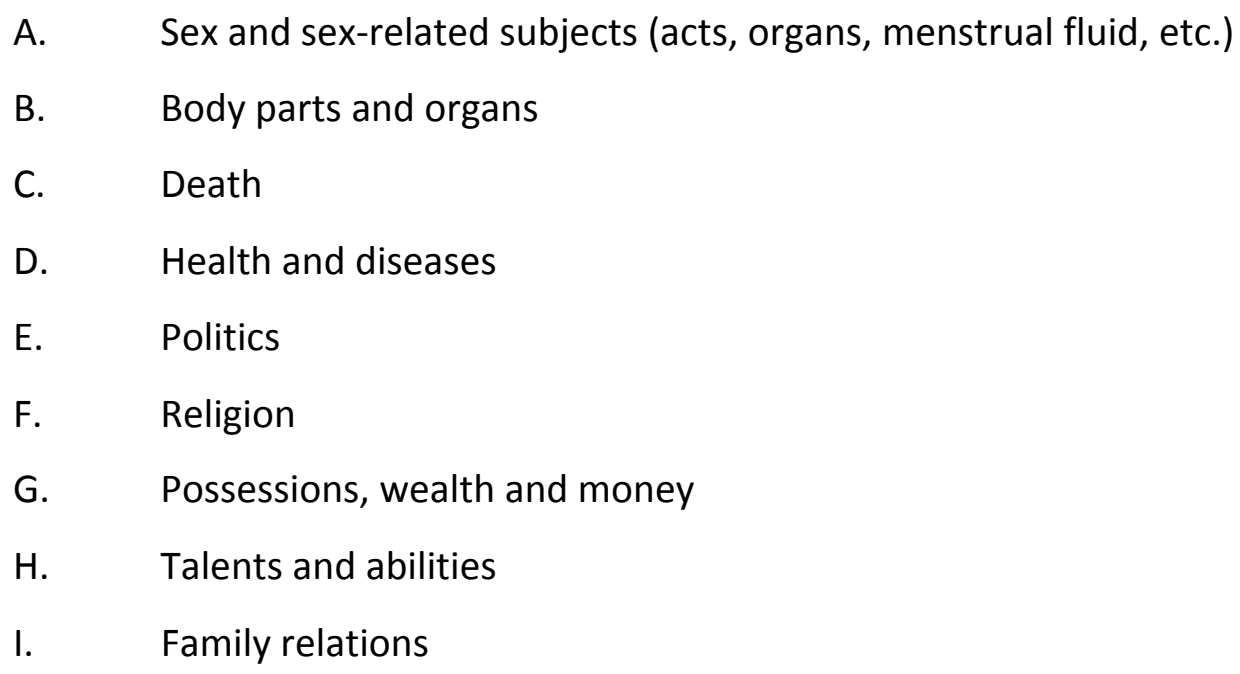

The literature on taboo language also highlights the importance of the aforementioned tabooed topics, and others, in language use. For example, Hysi (2011) focused on the use of taboos and euphemisms among women obtained similar results which confirm the findings of the present study. Cruse (2006) also enumerated such topics as money and religion, among others, as tabooed. Similarity is also seen between the taboo nature of 'family relations' found out in the current study and that of Mbaya's (2002) study of taboos in Oromo culture in Ethiopia. Sexual references were found to be considered to be tabooed by Chinyanganya (2013) as well, hence further supporting the current study. Other studies have also cast light on these subjects as being tabooed, particularly Keturi \& Lehmonen (2012) in Finnish textbooks of English as a Foreign Language (EFL) although it was further found that Keturi and Lehmonen talk of other areas of discourse like suicide as forbidden as well. These latter areas are not in line with the findings of the current study. On other hand, Keturi and Lehmonen found out that such areas as politics, religion, diseases and death are not tabooed.

\subsection{Discourse Strategies}

The second research question addressed the discourse strategies employed to deal with tabooed topics. The observations indicated that the above subject areas are treated in similar ways by means of certain strategies. These strategies included: 

A. Use of euphemistic language
B. Silence, avoidance or shift of the topic raised
C. Criticizing the speaker
D. Code-switching
E. Joking and witticism
F. Circumlocution and use of all-purpose words
G. Use of conventionally-fixed expressions
H. Change of tone, prosody and eye contact
I. Other

\subsection{Further elaboration}

This part elaborates on the strategies utilized by the interlocutors along with example(s) for each strategy. Topics that are considered tabooed, and therefore socially unspeakable, abound among Arabs. Sex and associations with it, whether through body organs such as genital organs or acts of sex including sexual intercourse and rape, can be considered to be the most tabooed subjects. The following observation displays an example of sex as a tabooed subject:

[Description of setting: In a family gathering consisting of adults and children, both men and women, an interlocutor starts talking about how the police arrest a man accused of attempting to abuse a little girl in Canada]

A. I read in the paper that the Canadian police have arrested a man for his attempt to abuse a little girl.

B. [a boy who did not hear well what speaker A said]: What did the police do?

C. [Speaker B's mother] Nothing!

This finding confirms Chinyanganya's (2013) results in the African language of Shona where it was found that hospital personnel who employed such strategies as euphemisms, code-switching and metaphors, among others, to avoid making direct references to HIV/AIDS which included sexual elements and was therefore viewed as 
tabooed. This and many other observations clearly indicated that while euphemistic language is employed when both adults and children are present, this language was rarely made use of where only children were present; that is to say, when the adults were absent. This finding supports Mwanambuyu's (2011) study in a Zambian context where it was found that euphemisms were utilized among adults far more frequently than among children.

In one case, a speaker talked about his dream of his brother's pregnant wife giving birth. The conversation which was too short is as follows:
A. Last night I dreamed that $N$ [wife of $A$ 's brother] had given birth.
B. [Harshly and forcefully] What an awful dream! Damn you and your dream!

The above answer is rooted in Arabs' customs. Based on an old and common belief, Arabs believe that dreams do come true, sooner or later, but 'in reverse'! That is to say, the reverse of a dream would happen; for instance, if somebody dreams of marriage, s/he will die and vice versa.

That brings the current discussion to another taboo: death. It was observed that topics that directly deal with death or indirectly contain elements of death are often replaced by euphemistic expression. For instance, instead of saying the word 'maat' (died), the interlocutors frequently utilized another term, 'tawaffa' (passed away) to refer to someone who has died. Speaking of death, it is interesting to see that the same verb, pass away, is utilized extensively in English as a euphemism.

Another interesting observation with regard to death was that while euphemistic expressions were frequently used in the case of close friends and relatives, this was not the case with acquaintances who were not very close in relationship. Therefore, of the afore-mentioned 'maat' and 'tawaffa', the former was employed in the case of close friends and relatives and the latter for acquaintances. This observation can be suggestive of the presence or influence of 'social distance' on the when and what of the use of euphemistic terms. Therefore, taking into account Allan \& Burridge's (2006: 1) claim that "Taboos arise out of social constraints", it might not seem irrelevant to argue that social distance serves as one of the social constraints on the use of euphemistic 
language. According to Sidnell (2009), previous research (e.g., Levinson 2002) has also pointed out the existence of certain taboos among relatives.

An example of politics as a tabooed topic occurred in a conversation in which a number of ten middle aged people were engaged. The interlocutors were conversing about various subjects when the conversation shifted to politics and one of the speakers stated that he had heard about the news of an attempt that had been made by the President's opponents to assassinate him. In reaction to this highly sensitive statement, a sudden silence fell over the room while one speaker stated,

A. Let's talk about what concerns us, not what doesn't. These [political issues] are none of our business.

As can be seen, the above statement is a request for topic avoidance. The speaker does not even name what he is conversing about (i.e., politics), preferring to refer to it by means of a pronoun (i.e., these). This demonstrates two facts about such a tabooed topic as politics. Put in simple terms, the speaker intends to achieve two aims: Firstly, he attempts to silence the interlocutor who had raised the topic and secondly, by using a pronoun (These) instead of naming the topic itself, he tries to show that he himself is also committed to what he is advising others to do. This avoidance of tabooed topics can be ascribed to the interlocutors' tendency to censoring what they view as socially inappropriate. Censorship is said to be a means of achieving linguistic purity and cleansing language of unspeakable elements (Allan \& Burridge 2006).

The next strategy observed was the use of code-switching. In this strategy, the interlocutors code-switched between Arabic and Persian and often expressed the tabooed topic/word in Persian rather than Arabic. This finding is confirmed by Verschueren (2003: 119) who asserted that "[...] code switching is a way of circumventing a social taboo". Interestingly enough, Verschueren also provided an example from Moroccan Arabic to illustrate his statement about the function of codeswitching. The following example depicts this strategy: 
[Description of setting: a number of teenagers and adults ranging in age from 15 to 29 are chatting informally about different things when the subject shifts to 'dirty talk']:

- [Speaker: a 29-year-old man] Raad [he wanted to] [switches to Persian] tartibesho bede! [do her]

In this regard, it can be hypothesized that Persian serves the purpose of reducing the taboo force of the even being conversed about but it is not clear how it functions so. Chinyanganya (2013) also posited that code-switching was one of the linguistic strategies utilized by hospital personnel in the African context.

Circumlocution, which is defined as "substituting a descriptive phrase for a word" (Parker \& Riley 2012: 256), was another strategy used by Arab interlocutors. The following short conversation between a teenage boy and his mother demonstrates this strategy. The boy is making reference to 'cancer' by means of 'a bad disease'. The boy's mother's reply sounded harsh, abrupt and terse and can be therefore deemed as being somewhat indirectly critical of the speaker's speech:
A. They say Mr. X has got a bad disease!
B. OK, I got it!

It was frequently observed that all-purpose words such as 'to do something with someone' were extensively utilized by women to refer to sexual abuse, particularly rape. To set an example, an Arab woman described how during war an Iraqi woman had been raped as follows:

- They left her in the desert after they had done many things with her.

The above description is too general; however, it is easy to decode the meaning on the basis of contextual information at hand.

Among the other taboo topics among Arabs are one's wealth, possessions, children, abilities and talents unless these are mentioned in a very gentle way 
accompanied by the use of certain euphemizing expressions. It is tenable to argue that taboos have roots in historical, cultural and economic factors of the society to which the Arab society is not an exception. This idea is supported by Johnson \& Johnson (1999) who found it to be true of the UK as well. Religious factors are also at work. The Arab community in Iran is devoutly religious such that invoking God's name is a means of avoiding 'evil eye' when one's possessions, wealth and children and their talents and abilities are mentioned.

The observations showed that this is accomplished mainly by accompanying one's speech with such conventionally-fixed expressions as 'Allah ikhallih' (May Allah preserve him), 'Allah yehfedhha' (May Allah preserve her), 'Allah yesterha' (May Allah protect him) and others. Most of these expressions have religious origins as they either invoke God's name (Allah in Arabic) or contain a religious element, especially the sacred word Allah. This finding further supports Ahmad et al.'s (2013) assertion that religious and cultural norms of the society are influential in the formation and use of different strategies to avoid taboos. Previous research has yielded similar results with regard to other religions, too. For instance, Dunai (2008), citing Hebrew as one such case, remarked that religion and profanity are closely linked. Dunai further argued that including a deity under the rubric of taboo is not new, highlighting the universality of the offence of tabooed language in terms of religion. To set an example, the following conversation is between a teenage boy who jokes about one of the Imams, that is, religious leaders of Islam. The conversation was faced with criticism on the part of the boy's father:

- Boy: Have you heard the joke about that man who decides to go and fight on the side of Imam [...]?

- Father [Angrily]: OK stop joking about holy people.

In the Arab community of the current study, it is widely believed that religious teachings in general, and the Koran, the Prophet Mohammed and Imams in particular, must be treated with utmost caution; otherwise conversing about them in an inappropriate or disrespectful manner is considered blasphemous. 
Non-verbal communication strategies were also at work in dealing with tabooed topics in conversation. This was reflected in the form of the change of tone, prosody and eye contact including gaze, stare and facial expressions. This strategy was observed mainly in interactions between children and their parents and was mostly utilized by adults interacting with teenagers and kids. The use of this strategy was observed to be increasingly motivated by issues that include sexual connotations or direct sexual references. Using this strategy amounts to the execution of power as the strategy was utilized by more powerful interlocutors (i.e., adults) to less powerful, if not interior, ones (i.e., children). More recent work by other researchers has led to similar findings as well. For instance, Sidnell (2009) stated that work by Levinson (2002) has demonstrated that some taboos are dealt with by means of eyebrow flashes and gaze.

Speaking of families and children, the observations revealed that, in Arabic context, elder people, both men and women, particularly those who are married and have children, are often referred to by use of 'Abu' (Father of) plus the name of the oldest, primarily, son or, secondarily, daughter. Therefore, it is considered particularly impolite to address a married man or woman by his or her first name and this must be preferably done as stated above. For instance, a man whose oldest son is named Ali is referred to as 'Abu Ali' (Ali's father). This observation further supports Mbaya's (2002) statement that using euphemisms is not merely a matter of decency but it can be based upon social conventions. The above observation is suggestive of the significance attached to names as indicative of one's identity as Allan \& Burridge (2006: 125) rightly pointed out, "One's name is an inalienable part of one's identity; it is the essence of self and it is a means by which one is known to one's fellows". Adding an affix, whether a prefix or a suffix, as a strategy to euphemize a naming taboo has been documented to occur in other communities and languages such as Pitjantjatjara, an Australian language, too (Allan \& Burridge 2006). Other sensitive family relations included those of mentioning one's sister. Arabs consider it highly impolite, and therefore socially unacceptable, to talk about their sisters unless the speaker is made to do so. This sensitivity is particularly intensified if the speaker is an outsider mentioning another individual's sister in public. However, in cases where this has to be done, a good deal of caution is exercised in that it is attempted, on the part of the speaker, that the mention 
be short and euphemized by the expression 'radhi'ah' (meaning a girl who has been breastfed by the same mother as the speaker's) to refer to 'sister'.

Furthermore, although it was not the objective to examine taboos and euphemisms in terms of the gender differences between males and females, it was also observed that females avoided naming taboos more frequently than males did. This observation is not new to the scene of sociolinguistic research as previous studies have documented women's speech to be more polite, cautious and decent and the results of the current study confirm those findings further (e.g., Haas 1979; Holmes 1989; Talley \& Hui-ling 2012).

The findings indicated that certain strategies are used with certain taboos. To set an example, while sexual topics were chiefly avoided or silenced, political topics were mostly shifted and the speakers were criticized. It can be hypothesized that while sexual references are most probably avoided because of the sensitivity toward social conventions, politics is feared.

\section{Conclusion}

It has been assumed that to understand cultural issues and human behavior, it is essential to understand the sociological aspects of language including taboos (Malmkjær 2002). The present study endeavored to expound an increasingly significant realm of language use: taboo and tabooed topics. Taboos have both a dark and a bright side as Freud (1913 [2001]) rightly pointed out. Interlocutors, however, seem to remain more alert to the dark side, that is, the social discomfort caused by the use of tabooed language.

The findings revealed that Arabs conceive of sex, death, health, diseases, politics, religion, possessions, wealth, money and family relations as tabooed subjects. They also make use of such strategies as the following to deal with the afore-mentioned tabooed topics: euphemisms, silence, avoidance or shift of topic, criticizing the speaker, codeswitching, joking and witticism, circumlocution and use of conventionally-fixed expressions. 
The findings clearly demonstrated that Arab speakers consider the act of breaking taboos to be closely associated with impoliteness while avoiding them would be necessarily conceived of as polite behavior. According to Brown \& Levinson (1987), making reference to sexual subjects with no attempt to soften the sexual load of the subject also suggests of 'politeness' which they term 'bald on record politeness strategy' characterized as being "completely open and direct, without any attempt to let the addressee preserve some freedom of action or some sense of equality" (Verschueren 2003: 45). Therefore, in relation to politeness and taking into account the other politeness strategies proposed by Brown \& Levinson (1987), we can hypothesize that utilizing different strategies to mitigate the socially unacceptable load of the taboo subjects is related to the interlocutors' attempt to display various degrees of politeness.

On the other hand, since, more often than not, it is maintained that politeness and indirectness are closely associated (e.g., Brown \& Levinson 1987; Verschueren 2003), then it is tenable to argue that avoidance of taboo topics, no matter what strategy this is achieved through, is intended to serve the purposes of politeness as well as establish and maintain harmony in social relations. In conclusion, along with such previous studies as Mwanambuyu (2011), the current study findings confirmed the hypothesis that the use of euphemistic language is affected by a number of factors such as the interlocutors' age, social distance, relative power, sex, the topic being conversed about, among others. It was also found that however palatable a euphemism is attempted to make an unspeakable even, situation or happening, there seem to exist some topics that are not mentionable. Isbuga-Erel's (2008) findings concerning the role of power relations and taboos are also illuminating in this regard.

On the contrary, it should be pointed out that some researchers have made it clear that using euphemistic language is associated with dishonesty and deceitful behavior. To set an example, O'Neill (2011) referred to the dishonesty lying at the heart of 'politically correct language'. This assumption, even if accepted, does not conflict with the assertion made in the current study as the major assumption here is that politeness, whatever the aim of the polite behavior is and by whatever means it is achieved, strives for social harmony and avoidance of disharmony in interaction (Olshtain \& Celce-Murcia 2003). The outcomes of the current study are expected to raise cross-cultural 
awareness, the lack of which can lead to serious breakdowns in communication between and among cultures.

In conclusion, Arab speakers seem to display varying degrees of sensitivity toward the taboo topics depending on the topic raised. In that regard, the highest sensitivity seems to relate to sexual topics which might have roots in the ancient traditions and customs of Arabs which dictate the norms based on which speakers should distinguish the 'speakable' topics from the 'unspeakable' ones. The way that this sensitivity is displayed is also diverse. For instance, it was observed that while sexual topics are especially avoided, death-related subjects are particularly reprehended. It is not fairly clear what this sensitivity is motivated by.

This observation might be explained on the grounds that euphemisms are divided into two types: positive and negative (Radulović 2012). This classification, however, does not seem to work fully for our observation as there are negative euphemisms that just sound more negative than others! Therefore, it might sound tenable to describe and view euphemistic language on a continuum rather than let the pendulum shift between the two extremes.

The door is left open to further research on taboo. Future research can, for instance, focus on the reasons behind using different strategies for different taboo topics or on exploring new areas of taboo under-examined in other cultures. On the plus side, future research can lead to the clarification of the role of metaphorical language in using euphemisms as Fernández (2008) clearly pointed out. Further, since taboos are not limited to the verbal communication and include the non-verbal realm of communication, it is recommended that future research focus on this aspect too.

Note. An earlier draft of this paper was presented under the title, "Euphemistic realizations of taboo subjects: The case of Arab community", at The Third International Conference on Language, Discourse and Pragmatics (LDP) held on January 28-30, 2015 at Shahid Chamran University of Ahvaz, Ahvaz, Iran. 


\section{References}

AHMAD, Khursheed, Mamuna GHANI, Mahtab ALAM, \& Tahir GUL (2013) “A sociolinguistic study of linguistic taboos in the Pashtoon society", International Researcher, 2, 1, 35-41.

AlLAN, Keith \& Kate BuRRIDGe (2006) Forbidden words: Taboo and the censoring of language, Cambridge: Cambridge University Press.

ARY, Donald, Lucy Cheser JACOBS \& Chris. K. SORENSEN (2010) Introduction to research in education (8th ed), USA: Wadsworth.

BRown, Penelope \& Stephen C. LEVINSON (1987) Politeness: Some universals in language usage, Cambridge: Cambridge University Press.

BUSSMANN, Hadumond (2006) Routledge dictionary of Language and Linguistics (Translated and edited by Gregory Trauth \& Kerstin Kazzazi), London: Routledge.

ChInYANgANYA, Taurai L. (2013) "Cultural linguistic strategies in HIV/AIDS discourse in Shona: A survey of Bindura Hospital", International Journal of Social Sciences \& Education, 3, 4, 1071-1079.

CRUSE, Allan (2006) A glossary of semantics and pragmatics, Edinburgh: Edinburgh University Press.

DUNAI, Amber (2008) Semantic shift and the link between words and culture. Unpublished Master's Thesis, University of North Texas, USA.

ENCYCLOPAEDIA BRITANNICA < www.Britannica.com> (Accessed December 20, 2014).

Epoge, Napoleon (2013) "Euphemism in Cameroon English: Sweet talking or deception?", International Journal of Innovative Interdisciplinary Research, 2, I, 1-10.

FERNÁNDEZ, Eliecer Crespo (2008) “Sex-related euphemism and dysphemism: An analysis in terms of conceptual metaphor theory", ATLANTIS. Journal of the Spanish Association of AngloAmerican Studies, 30, 2, 95-110.

FREUD, Sigmund (1913 [2001]) Totem and taboo (translated by J. Strachey), London: Routledge.

HAAS, Adelaide (1979) "Male and female spoken language differences: Stereotypes and evidence", Psychological Bulletin, 86, 3, 615-626.

HOLMES, Janet (1989) "Sex differences and apologies: One aspect of communicative competence", Applied Linguistics, 10, 2, 194-213.

HYSI, Eglantina (2011) "Aspects of taboos and euphemisms in women's language", Mediterranean Journal of Social Sciences (MCSER), 2, 3, 379-383. 
ISBUGA-EREL, Reyhan Funda (2008) "A CDA approach to the translations of taboos in literary texts within the historical and socio-political Turkish context", in Majid KhosraviNik \& Alexandra Polyzou (ed.), Papers from the Lancaster University Postgraduate Conference in Linguistics \& Language Teaching 2007, 2, 58-77.

JOHNSON, Keith \& Helen JOHNSON (eds.) (1999) Encyclopedic dictionary of applied linguistics, USA: Blackwell Publishers.

KETURI, Suvim \& Tiina LEHMONEN (2012) Though shalt not write about...: A study of taboo content in Finnish EFL textbooks for upper secondary school, Unpublished Master's Thesis, University of Jyväskylä.

LAKOFF, George \& Mark JOHnSON (1980) Metaphors we live by, Chicago: Chicago University Press.

LEVINSON, Stephen C. (2002) Manny's dangerous idea. Discourse studies. Talk given to the Center for Language, Interaction and Culture, UCLA.

LIE, Sondre (2013) Translate this, motherfucker!: A contrastive study on the subtitling of taboo words, Unpublished Master's Thesis, Universitetet i Oslo, Norway.

LINFOOT-HAM, Kerry (2005) "The linguistics of euphemism: A diachronic study of euphemism formation", Journal of Language and Linguistics, 4, 2, 227-263.

MALMKJER, Kirsten (2002) The linguistics encyclopedia, $2^{\text {nd }}$ ed., London: Routledge.

MbaYA, Maweja (2002) "Linguistic taboo in African marriage context: A study of the Oromo Laguu", Nordic Journal of African Studies, 11, 2, 224-235.

Microsoft ${ }^{\circledR}$ Encarta ${ }^{\circledR}$ 2009. (C) 1993-2008 Microsoft Corporation. All rights reserved.

MiRza SUZANI, Samad \& Lotfollah Yarmohammadi (2013) "An investigation of the semantic opaqueness and the state of affairs of English euphemisms in the Iranian educational context", Middle-East Journal of Scientific Research, 15, 11, 1540-1554.

Mwanambuyu, Christine Lubasi (2011) A Sociopragmatic Analysis of Silozi Euphemisms. Unpublished Master's Thesis, The University of Zambia, Lusaka.

OLSHTAIN, Elite \& Marianne CELCE-MURCIA (2003) "Discourse analysis and language teaching", in Deborah Schiffrin, Deborah Tannen, \& Heidi E. Hamilton (eds.), The handbook of discourse analysis, USA: Blackwell Publishing, 707-724.

O’NeILL, Ben (2011) “A Critique of Politically Correct Language”, The Independent Review, 16, 2, 279-291.

PAPI, Marcella Bertuccelli (2009) "Implicitness", in Jeff Verschueren \& Jan-Ola Östman (eds.), Key notions for pragmatics, The Netherlands: John Benjamins Publishing Company, 139-162.

PARKER, Frank \& Kathryn RILEY (2012) Linguistics for non-linguists, USA: Pearson. 
Dialectologia 18 (2017), 107-127.

ISSN: 2013-2247

QANBAR, Nada (2011) "A sociolinguistic study of the linguistic taboos in the Yemeni society", Modern Journal of Applied Linguistics, 3, 2, 86-104.

RAdULović, Milica (2012) "Expressing values in positive and negative euphemisms", Facta Universitatis, 10, 1, 19-28.

SIDNELL, Jack (2009) "Conversational analytic approaches to culture", in Jacob L. Mey (ed.), Concise Encyclopedia of Pragmatics, UK: Elsevier Ltd., 148-151.

STeIner, F. (1967) Taboo, UK: Penguin books.

TALLEY, Paul C. \& Tu HUI-LING (2012) "The influence of gender differences in proscribed language use in Taiwan", International Journal of Business and Social Science, 3, 20, 167-172. (Retrieved July 1, 2014, from <www.ijbssnet.com>.)

VernerovÁ, Simona (2013) "Characteristics of the language of advertising: Profanity in contemporary advertising", Unpublished Bachelor Thesis, Tomas Bata University, Zlín.

VERSCHUEREN, Jeff (2003) Understanding pragmatics, London: Arnold.

WARREN, Beatrice (1992) "What euphemisms tell us about the interpretation of words", Studia Linguistica, 46, 2, 128-172.

WIKIPEDIA <en.wikipedia.org> (Accessed December 20, 2014) 